Лена 3. Нинковић*

Универзитет у Београду

Филолошки факултет https://doi.org/10.18485/analiff.2020.32.2.20

811.111'23:811.163.41'23

Originalni naučni rad

Primljen: 10.06 .2020

Prihvaćen: 15.09 .2020

\title{
КОНЦЕПТУАЛИЗАЦИЈА НЕПРОТОТИПИЧНИХ ЕМОЦИОНАЛНИХ ПОЈМОВА ОДГОВОРНОСТИ, ПОШТОВАЫА И ОДАНОСТИ У СРПСКОМ И ЕНГЛЕСКОМ ЈЕЗИКУ
}

У овом раду испитују се начини концептуализације маргинализованијих чланова категорије емоција попут појмова ОДГОВОРНОСТИ, ПОШТОВАҢА и ОДАНОСТИ, који се не могу разумети без евоцирања скупа појмовних домена којем припадају. Истраживање појмова који су предмет анализе је засновано на когнитивнолингвистичком приступу, превасходно с циљем да се уоче појмовне метонимије, метафоре и метафтонимије које учествују у њиховом структурирању, а затим и да се испитају унутарјезичке и међујезичке сличности и разлике у концептуализацији поменутих појмова. Грађа за истраживање је прикупљена из корпуса опште намене, речника, као и дневне штампе. Резултати су показали висок степен сличности у погледу заступлљености метафора генеричког нивоа које се јављају у истим фазама когнитивног сценарија испитиваних појмова у оба језика, док се разлике испољавају у метафорама нижег реда општости, као и метонимијама и метафтонимијама које учествују у њиховом структурирању. Штавише, резултати указују и на унутарјезичке варијације у метафоричкој концептуализацији појма ОДГОВОРНОСТИ спрам појмова ПОШТОВАњА и ОДАНОСТИ у оба језика.

Кључне речи: когнитивна лингвистика, појмовна метафора, метонимија, емоције, српски језик, енглески језик.

\section{Увод}

Да су емоције чест предмет когнитивнолингвистичких истраживања, потврдила је литература (Lakoff, 1987; Lakoff \& Kövecses, 1987; Кликовац, 2004; 2018; и др.) која се бави проучавањем метафоричке и метонимијске концептуализације емоционалних појмо* lena.z.ninkovic@gmail.com 
Лена 3. Нинковић

ва, као и њихове организације у когнитивне моделе, од којих су несумњиво најистакнутија истраживања Золтана Кевечеша (1986; 1990; $2000 ; 2014)$. Поменути радови ${ }^{1}$ истичу тезу да се човекове емоционалне реакције сматрају резултатом когниције. Како сматра Кевечеш, емоционални појмови су организовани на основу четири структурне јединице: појмовне метонимије, појмовне метафоре, сродних појмова и когнитивних модела (прототипичних сценарија), који заједно чине комплексни когнитивно-културни модел емоције (Kövecses, 1990:198; 2000:127). Формулисањем теорије појмовне метафоре и метонимије, Џорџ Лејкоф и Марк Џонсон измештају метафору и метонимију из стриктно књижевних оквира у лингвистичке кругове (Lakoff \& Johnson, 1980). Према теорији појмовне метонимије, метонимија је когнитивни механизам којим један ентитет (преносник) омогућава приступ другом појмовном ентитету (циљу) у оквиру истог појмовног домена (Kövecses \& Radden, 1998:39), тј. когнитивног модела. Појмовне метонимије које су уочене као најизраженије у структури емоционалних појмова су УЗРОК ЕМОЦИЈЕ ЗА ЕМОЦИЈУ и ПОСЛЕДИЦА ЕМОЦИЈЕ ЗА ЕМОЦИЈУ (Kövecses, 2014:116). Метонимија се у случају ПОШТОВАҢА може илустровати примером из нашег корпуса у којем ЕМОЦИОНАЛНА РЕАКЦИЈА СТОЈИ ЗА ЕМОЦИЈУ (а која проистиче из утемељености емоција у нашем телесном искуству):

Како је познавао многе, чак скоро све, престао је најзад да враћа шешир на главу и пролазио је поред људи са метлама држећи шешир пред грудима, с наклоном йуним йошйовања $[\ldots]$ (КСCJ).

И док појмовна метонимија подразумева ментални приступ појму из истог појмовног домена, појмовна метафора омогућава разумевање појма из једног појмовног домена (циљног, апстрактног) помоћу другог појмовног домена (изворног, најчешће конкретног) (Lakoff \& Johnson 1980:5). Метафорички изрази представљају реализације поменутог механизма у језику (ibid.). Као пример навешћемо метафору ОДГОВОРНОСТ ЈЕ ТЕРЕТ која је најпродуктивнија у концептуализацији појма ОДГОВОРНОСТИ², а која се одсликава у примеру:

1 Такође в. и Fehr \& Russel, 1984; Polovina, 1996; Soriano 2015.

2 Што су потврдила и истраживања у енглеском језику: Kövecses 1990:65; 
КОНЦЕПТУАЛИЗАЦИЈА НЕПРОТОТИПИЧНИХ ЕМОЦИОНАЛНИХ ...

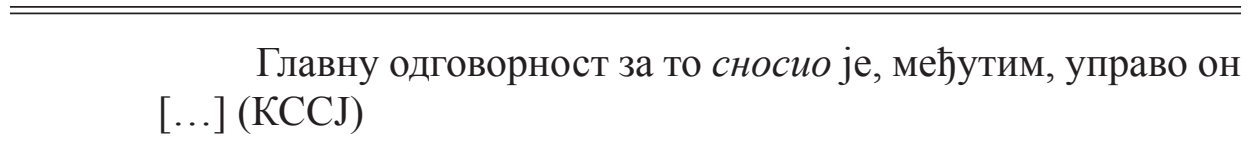

Како су емоције саме по себи нејасно оцртани појмови у искуственим доменима који се превасходно појме помоћу механизама метафоре и метонимије (Lakoff \& Johnson, 1980:85), проучавање емоционалних појмова засновано је управо на анализи њихових језичких реализација. Да метафоре могу ступити у интеракцију са метонимичном концептуализацијом, доказао је Хосенс (1990: 323-342) који уочава четири типа односа: 1 . метафора из метонимије; 2 . метонимија у оквиру метафоре; 3. деметонимизација унутар метонимије, и 4. метафора у оквиру метонимије. У испитивању поменутих емоција ми смо уочили други тип односа, превасходно у структури појма ОДГОВОРНОСТ, што ћемо подробније приказати у резултатима истраживања.

Прототипични случајеви емоција (попут среће, туге, страха, беса, и др) $)^{3}$ разумеју се помоћу когнитивног сценарија ${ }^{4}$ који подразумева одређени след догађаја (Lakoff, 1987:397-399; Kövecses, 2010:110; 2014:21), а који Кевечеш приказује на следећи начин: узрок

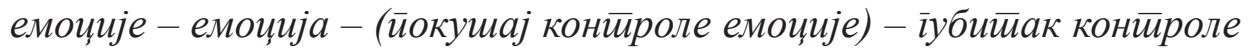
- емоционална реакиија (1990:184-186; 2000:58). Овакав когнитивни модел емоција потиче из народних теорија, пре свега да постоји одређени узрок емоције (спољашња ситуација, најчешће метафорички концептуализована као ФИЗИЧКА СИЛА) која доводи субјекта у одређено емоционално стање, а које затим у субјекту буди одређену емоционалну реакцију. Поменута структура емоционалних појмова је генеричког нивоа и, уз одређене интеркултурне и интракултурне варијације ${ }^{5}$, применљива на велики број емоционалних појмова.

1986: 27; Lakoff 1993:17; а такође је уочена у структурирању емоција уопште у Кликовац, 2000:202).

3 Ове налазе најпре је потврдила студија Ферла и Расела (1984:472) у којој су поменуте емоције оцењене као најбољи представници те категорије, а затим и Shaver et al., 1987: 1061-1086.

4 Одређење прототипичних когнитивних сценарија испитиваних емоционалних појмова превазилази оквире овог рада (за више о когнитивном сценарију појма RESPECT в. Kövecses, 1990:124).

5 Џорџ Лејкоф је испитујући појам љутње закључио да прототипични сценарио поменутог емоцоналног појма не мора нужно бити једини сценарио љутње, већ да различити контексти подразумевају изостајање одређених фаза, попут емоционалне реакције или контроле (Lakoff, 1987:399). 
Лена 3. Нинковић

Случајеви испитиваних појмова у овом раду представљали би, према поменутом сценарију, непрототипичне чланове категорије јер се у њиховој структури не јављају све фазе поменутог сценарија; често не постоји губитак контроле над емоцијом, нити типична физиолошка емоционална реакција, што потврђује и психолошка студија прототипичности емоционалних појмова (Fehr \& Russel, 1984). Наиме, од укупно две стотине испитаника и сто деведесет шест наведених емоционалних појмова, њих двоје је под појмом ЕМОЦИЈА навело ОДГОВОРНОСТ, седморо ПОШТОВАҢЕ, а четворо ОДАНОСТ, због чега их аутори означавају као непрототипичне представнике категорије емоција ${ }^{6}$. У српском језику, наведени емоционални појмови испитивани су у оквиру ширих анализа (Косановић 2016 - ПОШТОВАњЕ; Broćić 2018 - ОДГОВОРНОСТ; Кликовац 2018 - ОДГОВОРНОСТ), док је у енглеској литератури значајна студија Золтана Кевечеша (1990 - RESPECT).

У овом раду подробније се испитују метафоричка, метонимијска и метафтонимијска концептуализација емоционалних појмова ОДГОВОРНОСТИ, ПОШТОВАњА и ОДАНОСТИ у српском и енглеском језику како би се стекао свеобухватан увид у њихову непрототипичну природу, те и додатно потврдила теза о међузависности језика и мишљења. Поменути емоционални појмови одабрани су на основу заједничког критеријума побуђивања читаве доменске матрице - превасходно домена МОРАЛНОСТИ и ДРУШТВАㄱ, без којих разумевање поменутих непрототипичних појмова не би било могуће. Штавише, рад стреми и да предочи позитивно и негативно друштвено вредновање поменутих емоција.

\section{Доменска матрица и емоционални појмови}

Језички израз истовремено евоцира скуп домена (основних и неосновних) неопходних за његово разумевање, а који заједно чине

6 Додуше, исцрпну асоцијативну студију требало би извести и у српском језику ради свеобухватнијег увида у поменуте појмове.

7 Што налази и Косановић за поштовање које (према Robinson 2008) сврстава у друштвене емоције (2016:259), налазећи да прототипично произилази из односа са члановима заједнице, те се ван друштвеног контекста ретко јавља (мада се, наравно непрототипично, испољава и у односу према осталим живим и неживим ентитетима, попут животиња или идеала). 
КОНЦЕПТУАЛИЗАЦИЈА НЕПРОТОТИПИЧНИХ ЕМОЦИОНАЛНИХ ...

доменску матрицу (Langacker, 1987:147). Основни домени као области искуства које се не могу свести на нижу искуствену раван обухватају, inter alia ${ }^{8}$, и емоционално искуство. Основни домени искуства омогућавају концептуализацију великог броја појмова у нашем појмовном систему. Структура неосновних домена подразумева виши степен сложености, стога су на вишем нивоу од основних (претежно схематичних $^{9}$ ) домена. Управо ове неосновне домене лингвисти често називају оквирим $a^{10}$ услед још увек недовољне терминолошке усаглашености. Према Кевечешу (2013:77; 2014:23), емоционални појмови се могу разумети само на основу читавог оквира и других појмова из оквира којем припадају. Сваки емоционални појам који се из оквира ирофилише, тј. ставља у фокус, истовремено евоцира различите аспекте енциклопедијског знања говорника о том појму, што побуђује многобројне домене искуства који се међусобно преклапају. Избор домена и степен њихове активације зависи од контекстуалних и културних чинилаца. Како емоције настају у друштвеним околностима, често евоцирају домене ДРУШТВА, МЕЂУљУДСКИХ ОДНОСА, ДРУШТВЕНИХ НОРМИ; штавише, емоционални појмови евоцирају и домен ЉУДСКОГ ТЕЛА и његовог ФУНКЦИОНИСАҢА услед физиолошких реакција на емоцију; а како су често засноване на појмовима доброг и лошег, евоцирају и домен МОРАЛНОСТИ (ibid., р. 22).

\section{Корпус истраживања}

Као основни извори истраживања послужили су нам Корпус савременог српског језика Математичког факултета Универзитета у Београду $(K C C J)$ и Британски национални корпус (British National Corpus - BNC). Укупан број примера за српски језик јесте 2213, од тога

8 То су још и простор, време и чулни домени (опажајно, тактилно, аудитивно, моторно искуство). Увођењем поменутих термина Ланакер одбацује ранију дистинкцију између конкретних и апстрактних домена говорећи да сложеније мисаоне представе не морају нужно подразумевати апстрактно искуство.

9 Ланакер под схематичношћу подразумева нижи степен специфичности појмова, односно нижу информациону вредносt (1987:8).

10 Ослањајући се на теорију оквира Чарлса Филмора (в. Fillmore, 1982: 111137), Кевечеш први прави јасну разлику између домена и оквира наводећи да припадају различитим нивоима схематичности, те да оквири представљају специфичније јединице појмовне структуре (в. 2017: 321-347). 
Лена 3. Нинковић

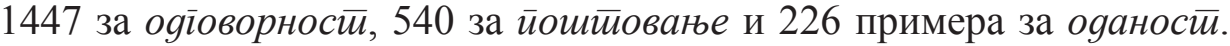
Број примера за енглески језик износи 2066, од којих 1012 за лексему responsibility, 652 за respect и 402 за лексему loyalty. Претрага корпуса извршена је према речима које означавају циљни домен, односно следећем скупу лексема у свим падежним облицима у српском јези-

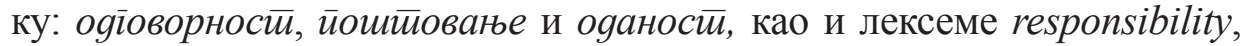
respect и loyalty у енглеском језику. Ради уочавања метафорички упо-

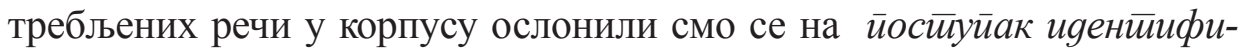
кације мешиафоре (Pragglejaz Group, 2007). Поменути квалитативни поступак подразумева: 1. Читање целог текста; 2. Дељење текста на лексичке јединице; 3 . Налажење потенцијално основнијег значења од контекстуалног (ослањањем на речник); 4. Одређивање потенцијалног контраста између основног и контекстуалног значења; 5. Потенцијално означавање лексичке јединице као метафоричке. Међутим, како се у српском језику метафоризација може испољити и у падежним облицима поменутих лексема, ради идентификације метафора определили смо се за верзију прилагођену српском језику тако да укључује и падежне метафоре које се најчешће одсликавају у генитиву, дативу, акузативу и инструменталу без предлога (Bogetić, Broćić \& Rasulić, 2019:205). Ради уочавања основног спрам контекстуалног значења лексема ослонили смо се на Речник срйскоїа језика Майице срйске (РСЈ), Речник срйскохрвайскої књижевноі и наровної језика САНУ (РСАНУ) и Речник савременой срииской књижевной језика с језичким савейником (РССКЈ) за потребе анализе српског, односно Oxford Advanced Learner's Dictionary (OALD) и електронске речнике Macmillan Dictionary (MD) и Cambridge Dictionary (CD) ради анализе енглеског језика. За прикупљање грађе такође смо се ослонили на интернет портале дневних новина и телевизијских програма (Полийика, H1, PTC, the Guardian) јер смо сматрали да би додатни подаци пружили свеобухватнију слику концептуализације одабраних емоционалних појмова.

\section{Концептуализација појма ОДГОВОРНОСТ/RESPONSIBILITY}

Услед комплексности појма ОДГОВОРНОСТ, уочене метафоре, метонимије и метафтонимије које леже у основи овог појма приказаћемо издвојено од остатка корпуса. Због обимности уочених метафора, у раду ћемо приказати оне најпродуктивније. 
ОДГОВОРНОСТ се најпре концептуализује као ПРЕДМЕТ који

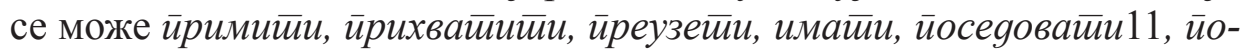

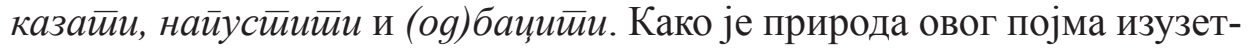
но сложена, пресликавањем поменутих елемената изворног домена ПРЕДМЕТА стиче се увид у скелетну структуру сценарија ОДГОВОРНОСТИ, односно узрочно-последичне повезаности СПОљАШњИХ ОДГОВОРНОСТИ које субјекта доводе у емоционално стање УНУТРАШЬЕ ОДГОВОРНОСТИ:

ПОЧЕТАК ОСЕЋАЬА ОДГОВОРНОСТИ ЈЕ ДОЛАЗАК У ПОСЕД ОДГОВОРНОСТИ-ПРЕДМЕТА $\rightarrow$ ОСЕЋАТИ ОДГОВОРНОСТ ЈЕ ПОСЕДОВАТИ ОДГОВОРНОСТ-ПРЕДМЕТ $\rightarrow$ ПРЕСТАНАК ОСЕЋАњА ОДГОВОРНОСТИ ЈЕ ОДБАЦИВАњЕ ОДГОВОРНОСТИ-ПРЕДМЕТА

Први део сценарија подразумева ентитет који субјекту одговорност може gонейи или gатии, док се у енглеском језику још може и

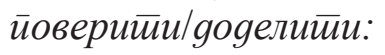

C

1. Одрастање gоноси са собом одговорност.

2. То је одговор обезвлашћеног који је неодговоран јер му се не gаје одговорност.

$\mathrm{E}$

3. It presumes the existence of at least two parties, one who allocates responsibility and one who accepts it.

4. In most firms it would be appropriate to delegate responsibility to one of the partners (or a committee) for ensuring that every member of the firm complies with the rules.

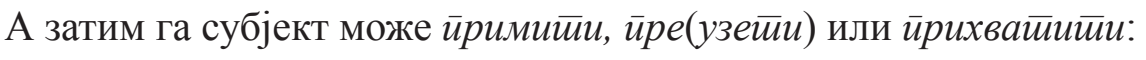

C

5. Најзад, ствар је сасвим могућа, потпуно по канонским прописима, за то ја иримам одговорност.

6. На пет минута до краја Оклахома је изједначила, а у тим моментима Крис Пол узима одговорност и води свој тим до победе.

7. У Америци је присутан велики бес, сматрају да нас Кина све вара, као и да Кина избегава да иреузме одговорност у контексту порекла вируса [...].

11 Кевечеш наводи ПОСЕДОВАҢЕ ПРЕДМЕТА као прототипични елемент метафоричких пресликавања на домен емоција, в. 2000:36. 
Лена 3. Нинковић

8. Схватам да вам није пружена могућности избора, госпођице Нево, али имајући на уму улог, морате у потпуности йрuхваиииии ту одговорност.

$\mathrm{E}$

9. Does the Prime Minister accept responsibility for the chaos and confusion at the heart of Governments over the Poll Tax?

Видимо, дакле, да спољашње материјалне, друштвене и животне околности приморавају субјекта на осећање одговорности, које се затим, у зависности од контекстуалних чинилаца, активира у садејству са доменом МОРАЛНОСТИ, и то осећањем (моралне) дужности/обавезе, што потврђује налазе да се појам ОДГОВОРНОСТИ налази „на међи" различитих домена искуства (превасходно моралности и емоција), стога се ни у једном домену не може посматрати као централна категорија, већ се зарад његовог разумевања евоцира читава доменска матрица. Елемент ПОСЕДОВАЊА одсликава се у следећим примерима у којима се реализује кроз глаголе који изражавају поседовање, присвојни генитив без предлога, као и присвојне придеве.

C

10. Као директор [...], имам Одговорност према будућности науке.

11. Покрет обнове Краљевине Србије (ПОКС) затражио је да се испита одговорност факулиетей и иррофесора који су били у комисији за спорни докторат [...].

12. То је моја лична одговорност, сињоре.

$\mathrm{E}$

13. In addition, the stewards handing out the hymn books require alerting and training in their responsibility in making the visitor welcome.

14. So responsibility was in your hands?

15. It must be for the local authorities, which have the statutory responsibilities.

Да је одговорност често непожељно и напорно стање које субјекта омета у свакодневном функционисању ${ }^{12}$ указује најпродуктивнија

12 На шта је указао и Џорџ Лејкоф говорећи о генеричкој метафори СТРУКТУРЕ ДОГАЂАЈА; НаИМе, УКоЛИКо сУ СВРСИСХДНЕ АКТИВНОСТИ КРЕТАҢЕ, потешкоће које нам отежавају кретање се метафорички поимају као TEPET. У 
конкретизована метафора ОДГОВОРНОСТ ЈЕ ТЕРЕТ који се субјек-

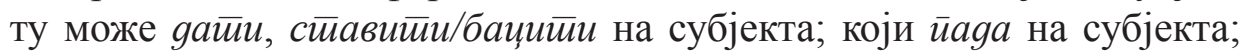

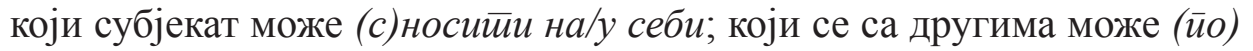

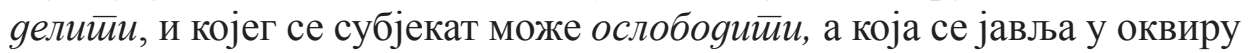
шире метафоре НЕЖЕЉЕНОГ ПРЕДМЕТА:

C

16. Он мора бити убеђен да постизање тог циља предста-

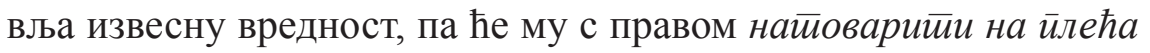
и одговорност за то.

17. [...] али се осећај кривице посрамљено повуче пред свешћу да му моћ намеће одговорности које захтевају и личне жртве.

18. Одговорност за рат сваљивана је на Југославију [...].

19. Младићу је деловало као да су се оне волшебне и неразмрсиве одговорности сручиле на њега.

20. Они имају право да бојкотују изборе, али немају право,

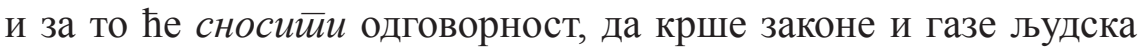
права и слободе.

21. Наставио је Бранко gа носи у себи иеешко осећање одговорности.

$\mathrm{E}$

22. There is a crucial role for partnerships in taking on responsibility for the local co-ordination of education

23. Up to the creation of the National Health Service in 1946 responsibility for the mentally ill and subnormal was carried largely by the local authorities.

24. On her shoulders, therefore, was placed a fair measure of responsibility.

25. What a miserable responsibility to be loaded with!

26. But others, too, must accept their share of responsibility for safety in the home.

Одговорност за (не)почињена дела видимо не само да пада на субјекта, већ са извесном силином делује на његово свакодневно

случају одговорности, кретање би се односило на животне активности. (в. Lakoff 1993:17). 
Лена 3. Нинковић

функционисање ${ }^{13}$. Штавише, одговорност која пада на субјектова плећа ${ }^{14}$ подразумева лоцирање одговорности, тј. ентитета који субјекту намеће одговорност у вертикалној равни изнаg њега, у складу са метафором МОЋ ЈЕ ГОРЕ, ЕНТИТЕТ У ОДНОСИ НА КОЈИ СЕ ИСПОљАВА МОЋ ЈЕ ДОЛЕ (Rasulić, 2004:253), стога је и ЕНТИТЕТ КОJЕМ CЕ НАМЕЋЕ ОДГОВОРНОСТ ДОЛЕ ${ }^{15}$. С друге стране, јављање осећаја одговорности у самом субјекту подразумева ношење ОДГОВОРНОСТИ-ТЕРЕТА У СУБЈЕКТУ-САДРЖАТЕЉУ.

Да вертикална димензија игра велику улогу у концептуализацији ОДГОВОРНОСТИ, посведочићемо следећим примерима:

27. Клијенти ове медицинске установе налазе се йog одговорношћу задртог човека.

28. Без одговарајућих информационих ресурса ни наставници од студената не могу захтевати вишу одговорност у процесу стицања знања.

29. Од најранијих почетака у српској библиографији био је споран симеиеен одговорности између писца и преводиоца књижевног дела.

30. Систем високошколског библиотечког пословања [подразумева] поштовање хијерархије одговорности унутар универзитета.

31. Он је аутор gруїої ранїа одговорности.

32. Дете је на најнижој лествици у хијерархији [...], да би се са вишим узрастом пело на лестивици моћи и одговорности.

Из приложеног видимо да се однос субјекта који испољава одговорност и ентитета према којем се одговорност испољава реализује предлогом $\bar{u} \circ g$ као прототипичним чланом просторне категорије,

13 Што је у складу са Кевечешевом тезом о двострукој сили која делује на субјекта: најпре спољашњој која у субјекту изазива емоцију, а затим и унутрашњој, односно самој емоцији која субјекта тера на (ре)акцију (в. Kövecses 2000:64) у складу са метафором вишег реда општости ЕМОЦИЈА ЈЕ СИЛА. Наравно, поменути догађај није увек заступљен, те се некада дешава да реакција на емоцију изостане.

14 НОСИТЕЉ одговорности може бити и човекова душа: Желим [...] и да се захвалим свима који за мене нису гласали јер су ми са душе скинули један велики терет одговорности [...]. (КССЈ)

15 Оваква концептуализација је сасвим јасно утемељена у телесном искуству ношења тешког предмета који подразумева физичку савијеност и отежано кретање. 
КОНЦЕПТУАЛИЗАЦИЈА НЕПРОТОТИПИЧНИХ ЕМОЦИОНАЛНИХ ...

чиме се наглашава међузависност два ентитета ${ }^{16}$, у горепоменутом случају кроз однос припадности. Одговорност се, као референтни ентитет (локализатор), налази са горње стране профилисаног ентитета (тј. објекта локализације) (27) (према Кликовац, 2000; 2004:113; 2018:42). У складу са метафором ВИШЕ ЈЕ ГОРЕ и ИНТЕНЗИТЕТ ЈЕ КОЛИЧИНА, субјекат може испољити вишу или мағу одговорност, те је СТЕПЕН ИСПОЉАВАЬА ОДГОВОРНОСТИ МЕРА КОЛИЧИНЕ ОДГОВОРНОСТИ-МАТЕРИЈЕ (28). Лексеме сииейен и ранй одговорности указују на квантитет одговорности која се може мерити у односу на неку референтну тачку $(29,31)$. Штавише, одговорност се јавља у спрези са појмом МОЋИ $(27,29,30,31,32)$, односно друштвеним статусом, те стицање високог друштвеног статуса подразумева и раст одговорности ${ }^{17}$, која из субјектове перцепције може бити окарактерисана као негативна појава ${ }^{18}$.

Најзад, одговорност се као НЕЖЕЉЕНИ ПРЕДМЕТ/ТЕРЕТ

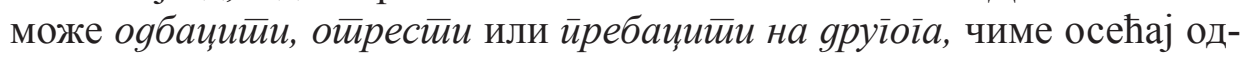
говорности престаје:

\section{$\mathrm{C}$}

33. [...] јесте, јер смо били неспособни да то урадимо сами, јер смо оgбацивали сваку, па и најмању одговорност $[\ldots]$.

34. Видели смо како жели да се одговорности ойресе и препусти је коцки.

35. Да ли те тај изговор чини саучесником, или те лишава одговорности?

$\mathrm{E}$

36. The process of psychology tends to offer a denial of personal responsibility in life

37. We will turn this responsibility over to them and will give our attention to prayer and the ministry of the word.

16 Расулић (2004) наглашава да предлог под подразумева већу међуповезаност ентитета који се доводе у везу, док предлог испод подразумева осетнију раздвојеност ентитета која се транспонује и на апстрактне домене.

17 У складу с метафором ВИСОК ДРУШТВЕНИ СТАТУС JЕ ГОРЕ (Lakoff \&Johnson, 1980:16) и ВЕЋА ОДГОВОРНОСТ ЈЕ ГОРЕ.

18 За висок друштвени положај карактеристично је везивање позитивних вредности: повољности, привилегије, углед, богатство, поштовање (в. Расулић, 2004:236). 
38. If the IRA think they can pass on their responsibility for this terrible act by issuing such a nonsensical statement, then they have sadly underestimated the understanding of the British public.

39. Responsibility for funding residential and nursing home care will be transferred from the Department of Social Security to local authority.

Видимо да концептуализација одговорности као терета ставља у фокус аспект когнитивног сценарија који се односи на емоиију-йокушај конироле емоције- немоіућносй конйроле емоције, када субјекат најпре носи одговорност, затим је сноси или gели са другима, и најзад је збаиује са себе (и, често, ирребаиује на неког другог) што може резултовати последњом фазом когнитивног сценарија - емоционалном реакиијом, која се може јавити у виду кривице (Broćić, 2018:379).

Одговорност се концептуализује и помоћу изворног домена БИЋА, чинећи тако другу најзаступљенију метафору вишег реда општости. Како тврди Золтан Кевечеш (Kövecses, 1990:166), емоције се могу поимати као бића чије „активности” не зависе од самог субје-

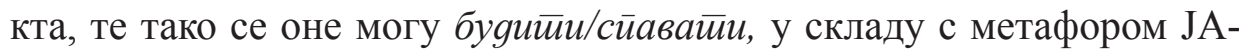
ВЉАЬЕ ОДГОВОРНОСТИ ЈЕ БУЋЕЊЕ ОДГОВОРНОСТИ-БИЋА У СУБЈЕКТУ-САДРЖАТЕЉУ (Klikovac, 2006:193). Штавише, ПОВЕЋАВАЮЕМ ИНТЕНЗИТЕТА ОДГОВОРНОСТИ доЛаЗИ дО ЈАЧАЬА/РАЗВИЈАЬА ОДГОВОРНОСТИ-БИЋА:

$\mathrm{C}$

40. Успевао је да на то подстакне многе људе доброг срца и да йробуgu осећање одговорности бар код неких представника власти.

41. Корона аларм - буђење личне и колективне одговорности.

42. У Бошку се тако и сувише усйавала одговорност.

43. Рано преузимање извесних, одређеном узрасту примерених радних обавеза, буgи и јача код деце осећање самосвести, одговорности и поуздања у сопствене снаге.

44. У прилагођавање безбедног окружења могу се укључити и старија деца чиме се код њих развија осећај одговорности. 


\section{$\mathrm{E}$}

45. Responsibility grew inside his maturing conscience. responds.

46. More responsibility comes with it, of course,' he

На нижем нивоу општости, ОДГОВОРНОСТ се може концептуализовати и као ПРОТИВНИК У БОРБИ, ПРОГОНИТЕЉ, УМАРАЧ $^{19}$; аЛИ и ДАРИВАЛАЦ и БОДРИЛАЦ:

\section{$\mathrm{C}$}

47. Бићете суочени с одговорношћу.

48. И он сада бежи од своје одговорности.

49. Њу саму, изморио је посао, одговорност, бриге.

50. Историјска одговорност обgарила ју је функцијом националне библиотеке [...].

51. Поястиакнуйе луцидношћу, одговорношћу [...] из библиографских бележака су стасале ретроспективна и текућа библиографија.

$\mathrm{E}$

52. Even if he were a king or at the least a count in eclipse, he would have faced danger and responsibility [...]

53. And the ending of the play is tantalisingly ambivalent, representing either a fresh start or a flight from responsibility, depending on your point of view.

54. Self-pity, and an escape from responsibility.

55. In my work I am driven by responsibility, professionalism and passion for what I do.

На основу примера из нашег корпуса приметили смо да одговорност не мора нужно имати негативну конотацију, те да може допринети позитивним резултатима које проистичу из извршавања дужности. Штавише, субјект који испољава одговорност и са одговорношћу приступа задатим обавезама изазива дивљење (C: Ja се овом gечаку gивим. Толико оgі̄оворносиии и храбростии никая нисам чуо; Е: She is admired for her sense of responsibility and morality).

19 У мањем броју примера је уочено да одговорност може бити и ВЛАДАР и МУЧИТЕЉ. Према Кевечешу, поменуте конкретизације потичу од метафоре генеричког нивоа НОСИЛАЦ ДРУШТВЕНЕ СИЛЕ (енг. SOCIAL SUPERIOR, в. Kövecses, 2000:21). 
Лена 3. Нинковић

Да домен МАТЕРИЈЕ представља чест изворни домен када је у питању концептуализација емоција (Kövecses, 1990; 2000), потврђује и наше истраживање. Тако ОДГОВОРНОСТ може бити НЕШТО ШТО ТЕК ТРЕБА ДА СЕ МАТЕРИЈАЛИЗУЈЕ (Према КЛИКовац, 2018:33), ДОК је ИНТЕНЗИТЕТ ОДГОВОРНОСТИ МЕРА КОЛИЧИНЕ ОДГОВОРНОСТИ-МАТЕРИЈЕ:

$\mathrm{C}$

56. [...] митски наивно, а истовремено временски рафинисано уобличавање људске одговорности према свим створењима.

57. На општем плану, то су питања о неgостиайку одговорности, каже уметник.

58. Држава, с обиљем одговорности, развија властиту бирократију.

$\mathrm{E}$

59. Are you totally without even a gram of responsibility?

ОДГОВОРНОСТ, затим, у српском корпусу може бити конкретизована и као ТЕЧНОСТ У САДРЖАТЕЉУ, а ИЗАЗИВАЮЕ ОСЕЋАЊА ОДГОВОРНОСТИ КОД ДРУГИХ ЈЕ УЛИВАҢЕ ОДГОВОРНОСТИ-ТЕЧНОСТИ У ЊИХ ${ }^{20}$ :

60. Живот је $\bar{u} y н$ обавеза и одговорности [...]

61. Истовремено се код људи мора улити и осећање одговорности у погледу располагања и трошења новца.

На основу речника и примера из корпуса закључили смо да је најпродуктивнија метонимија ЕМОЦИОНАЛНА РЕАКЦИЈА ЗА ЕМОЦИЈУ, као У случају метонимије УПИРАҢЕ ПРСТОМ ЗА ИЗАЗИВАЬЕ ОДГОВОРНОСТИ: Unhappy tourists have pointed the finger at unhelpful travel agents (CD); САВИЈЕН ТЕЛЕСНИ ПОЛОЖАЈ ЗА ОСЕЋАЮЕ ОДГОВОРНОСТИ: Не feels weighed down by all the assignments (MD). У српском језику наишли смо на фраземе који су мотивисани метонимијом ДЕО ТЕЛА ЗА ЧОВЕКА за значењем одбацити/наметнути/преузети одговорност: иррайи руке оg нечеїа (у са-

20 Што се истовремено може разумети и на основу метафоре ДРУШТВЕНЕ СИЛЕ која се служи ОДГОВОРНОШЋУ-СРЕДСТВОМ да би постигла жељени циљ. 
КОНЦЕПТУАЛИЗАЦИЈА НЕПРОТОТИПИЧНИХ ЕМОЦИОНАЛНИХ ...

дејству са метафором ОДГОВОРНОСТ ЈЕ МАТЕРИЈА); йоваритии некоме нешито на gушу, узети на своју gушу, иреузетии на своја йлећа (У садејству са метафором ОДГОВОРНОСТ ЈЕ ТЕРЕТ).

У анализи метафтонимија уочавамо суделовање већ поменуте метафоре ОДГОВОРНОСТ ЈЕ ТЕЧНОСТ и метонимије САДРЖАТЕЉ ЗА САДРЖАЈ:

62. Наступао је тренутак да се нешто предузме, морала

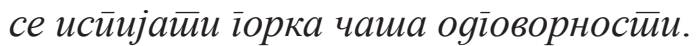

Затим, уочавамо интеракцију метафоре ДРУШТВЕНА ОРГАНИЗАЦИЈА ЈЕ КРУГ И МеТОНИМИје ОДГОВОРНОСТ ЗА ЕНТИТЕТ КОЈИ ИСПОљАВА ОДГОВОРНОСТ:

63. До сада не постоји ниједан званични документ на страни српске власти. Овај широки круі оgі̄оворностии не може gа објасни зашто је Стејт Департмент одбио учешће свог амбасадора у томе.

\section{Резиме}

На основу наведених примера и наша студија потврђује да се у оба језика одговорност превасходно концептуализује као ТЕРЕТ. Такође, изворни домен БИЋА у метафоричкој концептуализацији ОДГОВОРНОСТИ превасходно осветљава аспект јављања емоције у субјекту (под утицајем екстерних околности или других ентитета који на субјекта делују), затим постепеног јачања интензитета одговорности, а затим и дуготрајне манифестације одговорности ${ }^{21}$. Поменуте метафоре у фокус стављају догађаје когнитивног сценарија који се односе на фазе узрок-емочија и емоција. Изворни домен МАТЕРИЈЕ се прототипично односи на интензитет одговорности (Kövecses, 2000:41), односно на јављање осећаја одговорности у субјекту посредством других који желе да утичу на субјектово понашање и деловање.

\section{Концептуализација појмова ОДАНОСТ/ LOYALTY И ПОШТОВАЫЕ/RESPECT}

Услед уочених сличности у метафоричкој концептуализацији појмова ОДАНОСТИ и ПОШТОВАҢА, као и њиховом прототипично

21 Што потврђује и уочена метафора ОДГОВОРНОСТ ЈЕ ГРАЂЕВИНА и њена конкретизација ОДГОВОРНОСТ ЈЕ ТЕМЕљ. 
Лена 3. Нинковић

позитивном друштвеном вредновању, поменути појмови се у остатку анализе третирају заједно. Због обимности анализе у рад су увршћене само најпродуктивније метафоре, метонимије и метафтонимије.

Узроци оданости могу бити многобројни, те се може бити одан

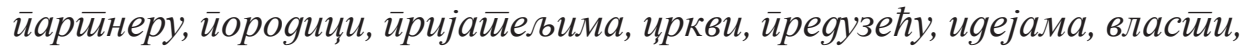
$u \bar{u} g$. Који ће cūeüен оданости субјект осећати према неком ентитету зависи од емоционалне блискости, али и субјектових моралних вредности које га нагнају на оданост, односно приврженост и деловање у складу с оним што се од њега очекује. Поменута два принципа не морају се јавити заједно; често је моралност једини узрок оданости, али се у том случају оданост односи на њену дуготрајну манифестацију која већ прераста у особину 22 онога који своје деловање управља према ономе што сматра исправним.

Узроци поштовања могу у субјекту изазвати непосредну емоционалну реакцију (на нечије моралне, интелектуалне, физичке особености и, ређе, друштвени положај $\left.{ }^{23}\right)$, или се она може дуготрајно манифестовати услед евоцирања и домена МОРАЛНОСТИ када често говоримо о поштовању норми, закона, ирравила, уреgби 24 , али и случајевима када се поштовање, односно понашање субјекта у складу са оним што се од субјекта захтева, йоразумева ${ }^{25}$, те указујемо поштовање било којој врсти ауторитета (пропраћену телесним манифестацијама), чак и када изостане непосредна емоционална реакција.

Први део когнитивног сценарија ОДАНОСТИ и ПОШТОВАњА подразумева метафоричку концептуализацију ОДАНОСТИ/ПОШОТОВАЊА као ПРЕДМЕТА, односно долазак у посед ПРЕДМЕТА, те се ОДАНОСТ/ПОШТОВАҢЕ у српском језику може сииворийи,

22 РСАНУ оданост дефинише као: „особину оног који је одан, приврженост, верност”. Исто налази и Броћић (2012) испитујући појмове ГОРДОСТИ, ОХОЛОСТИ И НАДМЕНОСТИ, а затим и Косановић истичући да емоције „подразумевају континуум између тренутних емоционалних епизода и људских особина (2016:8).

23 Која временом прераста у дуготрајни став.

24 Што РСЈ наводи под одредницом б: „придржавати се некаквих правила, закона, поступити, поступати у складу с нечим".

25 Што се усрпском језику реализује конструкцијом 'дужно поштовање', а у енглеском 'due respect'. 
КОНЦЕПТУАЛИЗАЦИЈА НЕПРОТОТИПИЧНИХ ЕМОЦИОНАЛНИХ ...

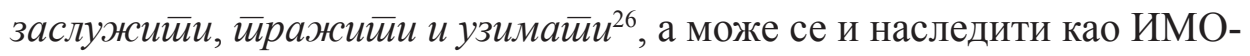

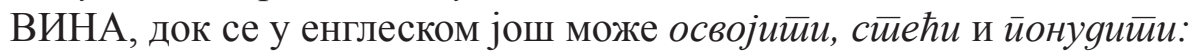

C

64. Такву оданост је сииворило чврсто уверење да се пољопривреднику може, и мора, помагати [...].

65. Оданост се заслужни, пре свега правим избором, зато је често нема.

66. Сувише су лепе да би биле верне, а мушкарци с годинама йраже оданост.

67. Желим поштовање; а то нам ти можеш сйећu.

$\mathrm{E}$

68. Marketing is about infinite improvements, by listening and by responding to people you increase involvement, engage commitment and win loyalty.

69. He soon proved himself a redoubtable warrior, and won the respect of his peers.

70. Jodie Foster offered him respect, helped him laugh away other people's pretensions.

71. But you did get respect from people.

72. It is difficult to gain their respect as an adult.

Да ОСЕЋАТИ ОДАНОСТ/ПОШТОВАҢЕ подразумева ПОСЕДОВАњЕ ОДАНОСТИ/ПОШТОВАҢА-ПРЕДМЕТА илуструјУ примери у

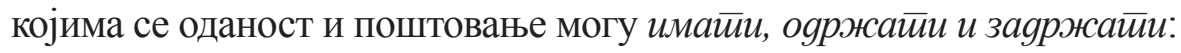

C

73. Оданост видим као карактерну особину, додуше не знам много људи који је ӣocegyjy.

74. Босански фратар и младић из Француске имали су очигледно још од оног првог сусрета на Купресу осећања симпатије и поштовања један према другоме.

$\mathrm{E}$

75. It is one thing for the Association to demand certain professional standards of its members and to expect them to have loyalty to these rather than to the employer in any dispute [...].

26 У складу са метафором ПОКУШАЈ ДА СЕ ИЗАЗОВЕ ОДАНОСТ У ДРУГИМА ЈЕ ТРАЖИТИ УЗИМАТИ ОДАНОСТ-ПРЕДМЕТ ОД ЊИХ (еНГ. ТRYING TO ATTAIN EMOTION IS SEARCHING FOR AN OBJECT, Stefanowitsch, 2006: 93). 
76. She returned after a ten year absence [...] consolidating the respect she held as one of Portugal's cultural leaders.

77. This refers to the ability of a group to retain the loyalty of its members and to attract new members.

78. President Najibullah has been meeting militia commanders offering them more weapons and money to maintain their loyalty.

Како се поштовање најчешће јавља с предлозима $y 3^{27}$ и $\mathrm{ca} /$ with, метафора ПРЕДМЕТА-ПРАТИОЦА показала се најучесталијом у целокупном корпусу оба језика:

$\mathrm{C}$

79. Пембертон се поклони пред њим $c a$ искреним поштовањем.

80. Улазак совјетских трупа на југословенску територију догађа се уз доследно поштовање начела о равноправности народа.

$\mathrm{E}$

81. I have worked loyally, shown you respect, but I too expect to be treated with respect.

Ретко, оданост и поштовање могу бити и ТЕРЕТ за субјекта којем се намећу:

82. Он је био ойиерећен [...] снажном, често емотивном оданошћу [...].

83. Како намеће поштовање према себи, чак и узаврелим масама које се налазе испод?

Карактеристично за концептуализацију ПОШТОВАњА јесте метафора ВРЕДНОГ ПРЕДМЕТА, односно РОБЕ/НОВЦА 28 или ДРАГОЦЕНОСТИ:29

27 РСЈ под наводницом 2. предлога уз означава: „правац кретања или место мировања сасвим блиско нечему”, док под тачком 3. подразумева: „заједницу: са, са собом; бити уз владу; имати новаца уза се”. Како не можемо тврдити да је оданост/поштовање ЧОВЕК који се налази у непосредној близини субјекта, прибегавамо другој могућности према којој је ОДАНОСТ/ПОШТОВАҢЕ ПРЕДМЕТ који СУБЈЕКТ ДРЖИ УЗА СЕ.

28 Што уочава и Кевечеш у енглеском језику.

29 Метафора ДРАГОЦЕНОСТИ уочена је и у структури ОДАНОСТИ на основу примера из српског корпуса, додуше у мањем броју примера. 
C

84. Сви прижељкују испуњен живот који обилује задовољством и успесима, који завређује поштовање људи чије поштовање вреgи имайи.

85.Исйоручийе господину генералу моје нарочито поштовање. Сада сам хтела да учиним нешто искреним осећањем, да часно не само куйим и йлайим твоју љубав, већ и поштовање.

86. И зато будите љубазни саопштити му да ме поштовање његових права сйаје шездесет или осамдесет хиљада пијастера.

87. [...] жудећи за тим да стекне његово поштовање, као да је то било најgраїоценије поштовање које се уопште могло стећи.

E

88. His achievements as Labour leader have earned him respect and admiration.

89. The report was asserting the responsibility of social workers and doctors to deal with the alleged victims and their parents in a way which paid respect to their feelings, loyalties and values, as well as their legal rights.

90. If we afforded them the respect they deserve [...] then the standard of service we would get would be a lot higher.

91. Only then would he be free to offer his father the respect he owed him.

Поменуту метафору ДРАГОЦЕНОСТИ и њену конкретизацију РОБЕ/НОВЦА нашли смо и у структури ОДАНОСТИ:

$\mathrm{C}$

92. Он занемарује чињеницу да ми gyīyje оданост као свом вођи [...]

E

93. The price for such loyalty, though, was high and Stamford was later ruined during the Wars of the Roses.

94. Instead of swearing allegiance to the Queen, members of the armed forces and new citizens will pledge their loyalty to Australia. 
95. In both cases loyalty was owed to the crown rather than the steward.

Типична за енглески језик јесте колокација unswerving loyalty, за коју сматрамо да преставља пример једне комплексне метафоре ДУГОТРАЈНО ИСПОЉАВАЮЕ ОДАНОСТИ ЈЕ ПРАВО КРЕТАҢЕ ${ }^{30}$.

Да је схема вертикалне димензије нарочито продуктивна у концептуализацији поштовања указују примери у којима ПОШТОВАњЕ може бити УЗВИШЕНО, а ЕНТИТЕТ ЗА КОЈИ СЕ ОСЕЋА ПОШТОВАњЕ ЈЕ ГОРЕ ${ }^{31}$ :

C

96. Поштовање грађанских права и слобода били су неирикосновени.

97. И ето, тај млади човек је био слеп и глув за све оно што је Давилу било најдраже, и изгледало једино gосйојно поштовања.

98. Могао је бити сјајан универзитетски професор, високо поштован члан друштва, интелектуални и финансијски аристократа.

99. Али изнаg родољубља стављаш поштовање према истини, научној истини [...].

100. Али је тек реформаторски жар Аменофиса узяиі̄ao поштовање бога gо невиђених висина.

$\mathrm{E}$

101. Tho' I highly respect Mrs. Leapor's character from the account you give of it, yet as she was absolutely unknown to myself, and I am but little acquainted even with her writings.

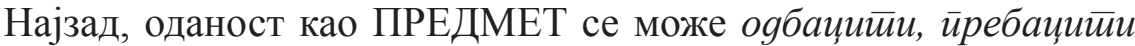

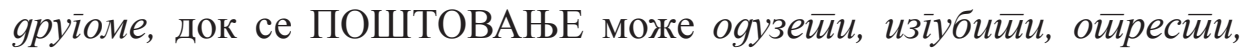

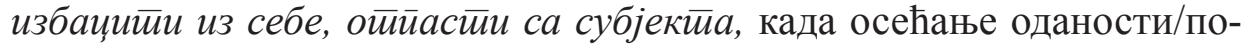
штовања престаје:

\section{$\mathrm{C}$}

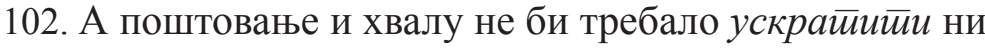
оним, рекосмо већ, често безименим.

30 (OALD) енг. to swerve - (especially of a vehicle) to change direction suddenly.

31 У складу са метафором ВРЕДНО ЈЕ ГОРЕ (према Расулић, 2004:210). 
КОНЦЕПТУАЛИЗАЦИЈА НЕПРОТОТИПИЧНИХ ЕМОЦИОНАЛНИХ ...

103. Погледајте око себе, кардинале. Људи су изіуубили поштовање.

104. Бајкић ипак није могао да се ойресе извесног поштовања за те људе.

105. Први пут онога дана да је он тотално збрисао родитељско поштовање из себе.

106. И да би се оне још више ослободиле, а са њега сасвим оййаo онај углед, поштовање, а с тим и страх, удари у мало масније задиркивање.

$\mathrm{E}$

107. Some party members found it hard to transfer their loyalty to the new leader.

108. Geographers who want to work in the environmental sciences must be willing to learn the methods of these sciences, lest we lose the respect of our colleagues in such fields.

Изворни домен БИЋА нарочито је продуктиван у етапама когнитивног сценарија које се тичу емоције-йокушаја конйроле емоичие-немогуућносии конйроле емоције. Фаза јављања оданостии кроз генеричку метафору БИЋА није забележена у корпусу српског језика, док ПОШТОВАЮЕ може бити зачет̄о, а затим се може и развијайи,

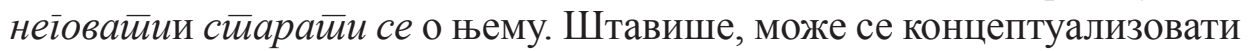
и као БИЋЕ У СУБЈЕКТУ-САДРЖАТЕЉУ:

109. Поштовање према Журајици, зачейо онога дана да оде пре него што се уселио, постајало је све сталније.

110. Агенција се стиара о заштити малолетника и поштовању достојанства.

111. И зато сам увек према њима развијао искрено поштовање.

112. Не селимо се у велике градове; неїујмо [...] поштовање које смо имали за наше претке.

113. У њему је пре свега йоgрхйавало поштовање према многољудности и многослојности која отежава приступ до жељеног скровишта.

Да се ОДАНОСТ и ПОШТОВАЬЕ могу конкретизовати као ЧОВЕК $^{32}$, сведоче и примери из нашег корпуса у којима је најчешћа

32 У случају оданости у питању је често слеп човек, на шта указује пример: 
Лена 3. Нинковић

конкретизација ПОШТОВАҢЕ НОСИОЦИ ДРУШТВЕНЕ СИЛЕ, и ТО ЧОВЕК КОЈИ КОТРОЛИШЕ СУБЈЕКТОВО ПОНАШАЮЕ, а У случају оданости то је ПРОГОНИТЕљ:

$\mathrm{C}$

114. Али Беатричу заустиави поштовање које се дугује празнику Богородице.

115. И то ће поштовање gржайи многе нације на окуйу.

116. Поштовање према човеку обавезује нас на поштвање закона.

117. Ипак, поштовање које су имале према мајци није gозволило том осећању да се увуче у њихова срца.

118. Али њено лично осећање поштовања према оцу сиречило ју је.

119. Слажем се да се оданости многи йлаше и чак беже од ње.

$\mathrm{E}$

120. Jürgen Klopp says timing and loyalty stopped him joining Manchester United.

121. This meant that loyalty forbade her to tell Philip who wouldn't have believed her in any case.

122. Loyalty sealed her lips, even with Liz and Esther, whom she at this period rarely saw.

С друге стране,у српском језику ОДАНОСТ/ПОШТОВАњЕ може бити човек неутралних или позитивних квалитета, стога се конкретизују као ПУТНИК, ВОДИЧ и УЧИТЕЉ:

123. Оданост - нешто што се ретко среће, можда и никада.

124. Поштовање једино воgи миру, равнотежи и заједничком опстанку.

125. Поштовање традиција моје нације ме је научило да с поштовањем приступам традицијама и ове земље.

126. Седа брада и седа коса, упорност да савлада све препреке путовања наилазили су на поштовање.

слепа оданост га је навела на пут таме. Међутим, као што ћемо касније видети, границе метафоре и метонимије у поменутој конструкцији најчешће нису оделите, те није сасвим јасно да ли је израз СЛЕПА ОДАНОСТ структуриран на основу једног, или другог когнитивног механизма, или пак, оба. 
КОНЦЕПТУАЛИЗАЦИЈА НЕПРОТОТИПИЧНИХ ЕМОЦИОНАЛНИХ ...

Као и у случају ОДГОВОРНОСТИ, ОДАНОСТ и ПОШТОВАњЕ могу бити МАТЕРИЈА: Та материја у случају ОДАНОСТИ може бити ТЕЧНОСТ У СУБЈЕКТУ-САДРЖАТЕЉУ, ТОПЛОТА, СВЕТЛОСТ:

\section{$\mathrm{C}$}

127. Правољубивост, оданост и милосрђе, одједном ме свег исиинише.

128. А биле су дошле да хладну гробну плочу заіреју йойлином своје љубави, своје верности и своје оданости.

129. Оно што дефинитивно зрачи из њиховог карактера јесте оданост и подршка онима које воле.

$\mathrm{E}$

130. Many migrants once voted Tory. Now their loyalty is fading fast.

ПОШТОВАЮЕ мОЖе бИТИ ТЕЧНОСТ: У САДРЖАТЕЉУ, ТЕЧНОСТ У (ПРЕПУНОМ) СУБЈЕКТУ-САДРЖАТЕЉУ, ДОК ИЗАЗИВАњЕ ПОШТОВАЮА КОД ДРУГИХ Подразумева УЛИВАњЕ ПОШТОВАҢА-ТЕЧНОСТИ У ЊИХ:

C ски.

131. Воли те, йун дубоког поштовања, рођак Кшешов-

132. Та интелектуална веза [...] између Андрића и Јеремића не исрпљује се само овим Андрићевим изливима поштовања $[\ldots]$.

133. Тим лицем човек не може да придобије симпатију, а поштовање и страх које улива људима није довољно за вођу.

E

134. It was their job to instill respect into these 50 young initiates - respect and the essential knowledge of womanhood: bitter knowledge; sweet knowledge.

Метонимије структурирају нарочито важан аспект појма ПОШТОВАњА, и то онај који нам говори о физичкој манифестацији поштовања као непосредне емоционалне реакције (најчешће на нечији друштвени статус) с једне, и као захтеваног обрасца понашања, с друге стране. Кевечеш уочава да се у основи поштовања изазваног нечијим моралним ставовима/поступцима, интелектуалним и физич- 
Лена 3. Нинковић

ким способностима не налази типична телесна реакција, већ то могу бити различите форме учтивости (Kövecses, 1990:120). Поменута метонимија подразумева случај када ЕМОЦИОНАЛНА РЕАКЦИЈА стоји ЗА ЕМОЦИЈУ:

$\mathrm{C}$

135. Пролазио је поред људи с метлама, gржећи шешир ирер ірудима, с наклоном пуним поштовања.

136. Старац јој се gубоко клањао и изговарао звучне поздраве и комплименте.

137. Латио се тешког посла пред почетак квалификација и за то му скияам кайу.

138. Када је француски маршал клечао пред фирером и када су из пивнице урлици допирали и до нас [...].

139. Већ његова жена примала је знаке младићевог поштовања, имајући на уму његово ниже порекло и имовно стање који, чинило јој се, йакво яржање налажу.

$\mathrm{E}$

140. In a further nod of respect to the great helmsman, his portrait on the Forbidden City has been given a new look.

141. Last night in the Olympic Stadium, Rome bowed to ${ }^{33}$ Paul Gascoigne.

142. She phrased that as a question, out of respect for etiquette.

С друге стране, у структури појма ОДАНОСТ уочавамо метонимију ЕМОЦИЈА ЗА МАНИФЕСТАЦИЈУ ЕМОЦИЈЕ посведоченУ у следећим примерима:

143. За странку попут СНC која не пропушта прилику да јавно исииакне своју оданост европским вредностима [...].

144. Све политичке снаге имале су довољно времена да нашем народу gемонстирирају своју приврженост и оданост родној груди.

145. То даје Унији додатан маневарски простор да у међувремену притиска Београд да се мање ослања на Москву, и исйољи већу оданост Бриселу него руском медведу.

33 Премда је поменути израз идиоматске природе, утеловљен је у искуству савијености тела на доле како би се физичком реакцијом указало поштовање. 
КОНЦЕПТУАЛИЗАЦИЈА НЕПРОТОТИПИЧНИХ ЕМОЦИОНАЛНИХ ...

Говорећи о конструкцији СЛЕПА ОДАНОСТ, истакли смо да није увек јасно да ли је поменути израз проистекао из метафоре или метафтонимије. И заиста, уколико је оданост човек којем су приписане људске особине, онда би у питању био метафорички принцип:

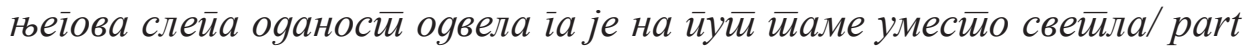
of the story seems to be historical accident, followed by blind loyalty to institutionalized habits.

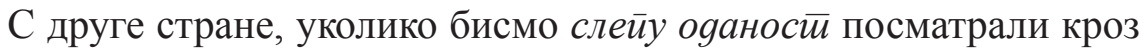
метонимију ЕМОЦИЈА ЗА ЕМОЦИОНАЛНУ РЕАКЦИЈУ, а сЛеПиЛО кроз примарну метафору ЗНАҢЕ ЈЕ ВИЂЕЊЕ, такав израз би се односио на људе који непромишљено делају у складу са оним што се од њих захтева, те се њима лако може манипулисати:

\section{C}

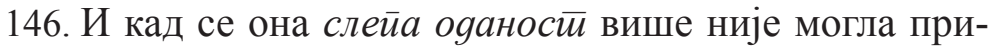
родно изазвати, онда им [политичарима] ништа друго није преостало него да обнове патриотизам.

E

147. We should understand that in the age of Donald Trump, blind loyalty is unlikely to earn us the respect we will need to have a chance of influencing policy in Washington.

\section{Резиме:}

Најпродуктивнија метафора вишег реда општости у концептуализацији ПОШТОВАњА и ОДАНОСТИ јесте метафора ВРЕДНОГ ПРЕДМЕТА, што указује на превасходно позитивно вредновање особа које их испољавају. Метонимије структурирају фазу манифестације емоције, била она физичка или вербална. Метафтонимија је уо-

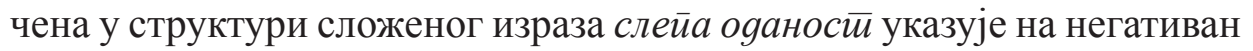
аспект оданости када се она не јавља у самом субјекту, већ је изазвана посредством спољног ауторитета.

\section{Закључна разматрања}

На основу изложених резлултата истраживања стиче се увид у појмовно-значењску структуру испитиваних емоција, али и сличности и разлика које се уочавају у фазама когнитивног сценарија и метафоричкој концептуализацији на различитим нивоима општости. 
Лена 3. Нинковић

Наиме, оно што је карактеристично за оgі̄оворносй јесте покушај одупирања субјекта осећању одговорности које се реализује најчешће кроз субјектову невољност пропраћену негативним емоцијама попут патње, туге, емоционалног бола, менталног умора. Оваква концептуализација потиче од поимања одговорности као ТЕРЕТА - метафоре нижег реда општости која је најпродуктивнија у структури појма ОДГОВОРНОСТИ у оба корпуса, а која је готово неприметно заступљена у структури појмова ПОШТОВАЮЕ и ОДАНОСТ (у само 5 примера у структури појма ПОШТОВАњЕ и 3 примера у структури појма ОДАНОСТ у примерима из српског корпуса, односно није заступљена у структури испитиваних појмова у примерима из енглеског корпуса). На основу поменуте метафоре стичемо увид у негативно вредновање одговорности из перспективе субјекта који је осећа. Како физички терет онемогућава кретање и изазива телесне манифестације попут савијености и умора, тако и ментални терет отежава субјектово стабилно психичко функционисање и изазива друге негативне емоције. Штавише, структурирање појма ОДГОВОРНОСТИ на основу конкретизација метафоре БИЋА као ПРОТИВНИКА У БОРБИ и ПРОГОНИТЕЉА (која је најчешћа у оба језика), говори у прилог негативном вредновању одговорности као дуготрајним стањем. С друге стране, концептуализација одговорности као ВРЕДНОГ ПРЕДМЕТА, тј. УКРАСА, сведоче о позитивном друштвеном вредновању ентитета који одговорност испољава, док подметафоре ВОДИЧА и УЧИТЕЉА у примерима из српског корпуса наглашавају поучни карактер одговорности као дуготрајне манифестације. Одговорно делање у складу са сопственим и туђим очекивањима изазива осећај задовољства; неодговорно делање прототипично изазива осећај кривице, која се јавља у спрези с доменом моралности. Непрототипично, субјект нема развијена морална начела, те изостаје и осећај кривице.

Емоције попут поштовања и оданости завређују позитиван однос субјекта према емоцијама које осећа, као и ентитета према којем се поменуте емоције испољавају, што се уочава у метафоричкој концептуализацији ПОШТОВАњА/ОДАНОСТИ као ВРЕДНОГ ПРЕДМЕТА/ДРАГОЦЕНОСТИ, ПРЕДМЕТА КОЈИ ТРЕБА ЗАСЛУЖИТИ, СВЕТЛОСТИ, ТОПЛОТЕ. У приЛог ТОме сведоче и сродни појмови који се јављају уз поменуте емоције: пажња, дивљење, наклоност/љубав, посвећеност, поверење, искреност, чедност. Међутим, оданост се 
КОНЦЕПТУАЛИЗАЦИЈА НЕПРОТОТИПИЧНИХ ЕМОЦИОНАЛНИХ ...

може и испољити као изразито негативно стање (радије него осећање) онда када субјект није сасвим свестан, или не контролише сопствене поступке, већ се води речју и понашањем ауторитета. Овакво стање подразумева одређено трајање и код субјекта временом изазива „слепило" у виду металног и моралног пропадања. Такође, принудно исказивање поштовања без било какве манифестације поштовања као емоционалног става код субјекта изазива осећај обавезе, потчињености и, ређе, срама.

\section{ЛИТЕРАТУРА}

Bogetić, K., Broćić, A. \& Rasulić, K. (2019). Linguistic metaphor identification in Serbian. In S. Nacey, et al. (Eds.). Metaphor Identification in Multiple Languages: MIPVU around the world, Amsterdam: John Benjamins, pp. 204-226.

Броћић, А. (2012). О концептуализацији појмова ПОНОС, ГОРДОСТ, ОХОЛОСТ и НАДМЕНОСТ у српском језику. Зборник Майице срйске за филолоїиуу и линіввистику XV/2, 119-140.

Broćić, A. (2018). Konceptualizacija emocija samovrednovanja u engleskom i srpskom jeziku. Doktorska disertacija. Beograd: Filološki fakultet.

Fehr, B. \& Russell, A. J. (1984). Concept of Emotion Viewed From a Prototype Perspective. Journal of Experimental Psychology: General, vol. 113, No. 3, pp. 464-486.

Fillmore, J. C. (1982). Frame Semantics. Linguistics in the morning calm. Soeul: Hanshin Publishing Company, pp. 111-137.

Goosens, L. (1990). Metaphtonymy: the interaction of metaphor and metonymy in expressions for linguistic action. Cognitive Linguistics, 1(3), 323-342.

Klikovac, D. (2000). Semantika predloga: studija iz kognitivne lingvistike. Beograd: Filološki fakultet.

Klikovac, D. (2004). Metafore u mišljenju i jeziku. Beograd: Biblioteka XX vek. Кликовац, Д. (2018). Срйски језик у свейлу коїнийивне линївистиике. Београд: Друштво за српски језик и књижевност Србије.

Kosanović, M. (2016). Pridevi koji označavaju emocije u engleskom i srpskom jeziku: kognitivnolingvistička analiza. Doktorska disertacija. Beograd: Filološki fakultet.

Kövecses, Z. \& Radden, G. (1998). Metonymy: Developing a Cognitive Linguistic View. Cognitive Linguistics, 9 (1), pp. 37-78.

Kövecses, Z. (1990). Emotion Concepts. Berlin \& New York: Springer-Verlag. 
Лена 3. Нинковић

Kövecses, Z. (2000). Metaphor and Emotion. New York \& Cambridge: Cambridge University Press.

Kövecses, Z. (2013). The Metaphor-Metonymy Relationship: Correlation Metaphors Are Based on Metonymy. Metaphor and Symbol, pp. 75-88.

Kövecses, Z. (2014). Conceptualizing Emotions: a revized cognitive linguistic perspective. Poznan Studies in Contemporary Linguistics, pp. 15-29.

Kövecses, Z. (2017). Levels of metaphor.Cognitive Linguistics, 28(2), pp. 321-347.

Langacker, R. (1987). Foundations of Cognitive Grammar. Theoretical Prerequisites. Stanford: Stanford University Press.

Lakoff, G. \& Johnson, M. (1980). Metaphors We Live By. Chicago: Chicago University Press.

Lakoff, G. \& Kövecses, Z. (1987). The cognitive model of anger inherent in American English. In D. Holland \& N. Quinn (Eds.). Cultural Models in Language and Thought (pp. 195-221). Cambridge \& New York: Cambridge University Press.

Lakoff, G. (1987). Women, Fire, and Dangerous Things: What Categories Reveal about the Mind, Chicago: Chicago University Press.

Lakoff, G. (1993). Contemporary Theory of Metaphor. In A. Ortony (ed.). Metaphor and thought ( $2^{\text {nd }}$ edition). Cambridge: Cambridge University Press, pp. 202-251.

Polovina, V. (1996). Prilozi za kognitivnu lingvistiku. Beograd: Filološki fakultet. Pragglejaz Group (2007). MIP: A Method for Identifying Metaphorically Used Words in Discourse. Metaphor and Symbol. 22 (1), 1-39.

Rasulić, K. (2004). Jezik i prostorno iskustvo. Beograd: Filološki fakultet.

Shaver, P. R., Schwartz, J., Kirson, D. \& O’Connor, C. (1987). Emotion knowledge:

Further explorations of a prototype approach. Journal of Personality and Social Psychology, 52, 1061-1086.

Soriano, Ch. (2015). Emotion and conceptual metaphor. In H. Flam and J. Kleres (Eds.). Methods of Exploring Emotions (pp. 206-214). New York \& London: Routledge.

Stefanowitsch, A. \& Gries, S. (Eds.). (2006). Corpus-based Approaches to Metaphor and Metonymy. Berlin \& New York: Mouton de Gruyter.

\section{ИЗВОРИ}

КССЈ - Корӣус савременої срӣскоі̄ језика, <http://www.korpus.matf.bg.ac.rs/> 9.06.2020.

РСЈ - Речник срйскойа језика. (2007). Нови Сад, Матица српска.

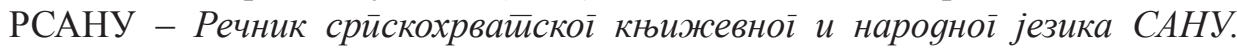
(1959-).I-, Београд: САНУ. 
Московљевић, М. (2000). Речник савременой срйской књижевної језика с језичким саветиником. Београд: Гутенбергова галаксија.

Пипер, П., Драгићевић, Р. и Стефановић, М. (2005). Асочијайивни речник срйскоїа језика. Београд: Београдска књига.

Политикка $<\mathrm{http}: / /$ www.politika.rs/> 2.06.2020.

$H 1<\mathrm{http}: / / \mathrm{rs} . \mathrm{n} 1$ info.com/ 30.05.2020.

PTC $<$ http://rts.rs $>31.05 .2020$.

BNC - British National Corpus <http://corpus.byu.edu/bnc > 12.06.2020.

OALD - Oxford Advanced Learner's Dictionary (2010). Oxford: Oxford University Press.

MD - Macmillan Dictionary <https://www.macmillandictionary.com>

$\mathrm{CD}$ - Cambridge Dictionary <https://dictionary.cambridge.org>

The Guardian <https://www.theguardian.com/international> 8.06.2020.

\title{
Lena Ninković
}

\section{CONCEPTUALIZATION OF NON-PROTOTYPICAL EMOTION CONCEPTS OF RESPONSIBILITY, LOYALTY AND RESPECT IN SERBIAN AND ENGLISH}

\begin{abstract}
Summary
This paper explores the conceptualization of marginal members of emotion category in the English and Serbian language, such as ODGOVORNOST, POŠTOVANJE, and ODANOST ('RESPONSIBILITY', 'RESPECT' and 'LOYALTY', respectively), that cannot be understood without evoking an array of conceptual domains. This research is based on the cognitive-linguistic approach, with the primary aim of identifying the conceptual metonymies, metaphors, and metaphtonimies that structure the abovementioned concepts and examining the intralingustic and interlinguistic similarities and differences in their conceptualization. The reseach data was obtained from general corpora, dictionaries, and daily newspapers. The results have shown a high degree of similarity in terms of generic level metaphors that occur in the same phases of cognitive scenarios of the examined emotion concepts, while the differences occur in the elaborated cases of metaphors and metonymies that structure the abovementioned concepts. Furthermore, the results have indicated intralinguistic variation in metaphorical conceptualization of the concept of RESPONSIBILITY as opposed to the concepts of RESPECT and LOYALTY in both languages.
\end{abstract}

Keywords: cognitive linguistics, conceptual metaphor, metonymy, emotions, Serbian language, English language. 